\title{
Urban Planning and Socioenvironmental
}

Disasters: The Myth of Urban Expansion in Blumenau/SC

\begin{tabular}{l|l|l|}
\hline Date received: 27 May 2019 | Date approved: 16 July 2019 | Date published: 29 May 2020 \\
Leandro Ludwig \\
\hline $\begin{array}{l}\text { Regional University of Blumenau Foundation } \\
\text { (FURB), Brazil }\end{array}$ & ORCID: 0000-0002-6487-1521 & Ieandroludwig@live.com \\
\hline
\end{tabular}

Marcos Antonio Mattedi

Regional University of Blumenau Foundation

(FURB), Brazil

ORCID: 0000-0002-0046-7853

Maria Roseli Avila

Regional University of Blumenau Foundation

(FURB), Brazil

Abstract This text aims to address the relationship between social-environmental disasters and the Urban Planning in the definition of urban expansion strategies from Blumenau to the North Region of the city. It is argued that the city was modified from two processes: 1) The effects of urban planning (generated by the idea of an ideal city); 2) the disaster effects (generated by the actual city). From these two processes, this text evidences that the strategies of the Urban and Regional Planning of Blumenau constitute social markers of the segregating effect of disasters. In order to develop this argument the text is structured in three main sections: 1) The formation and urban development of Blumenau; 2) disasters and the myth of urban expansion to the Northern Region; 3) the relationship between disasters and the limits of Urban Planning.

Keywords natural disaster, urban expansion, urban planning, urban voids, Blumenau 


\section{La planificación urbana y los desastres}

socioambientales: el mito de la expansión urbana en Blumenau/SC

Resumen Este artículo aborda la relación entre los desastres socioambientales y la Planificación Urbana bajo la definición de las estrategias de expansión urbana en Blumenau, en la región norte de la ciudad. Se plantea que la ciudad se vio modificada a partir de dos procesos: 1) los efectos de la planificación urbana (derivada de la idea de una ciudad ideal); 2) los efectos de los desastres (generados por la ciudad real). A partir de esos dos procesos, este artículo evidencia que las estrategias de la Planificación Urbana y regional de Blumenau constituyen marcadores sociales del efecto segregador de los desastres. Para desarrollar este argumento, se estructura el texto en tres secciones principales: 1) La formación y el desarrollo urbano de Blumenau; 2) los desastres y el mito de la expansión urbana hacia la región norte de la ciudad; y 3) la relación entre los desastres y los límites de la Planificación Urbana.

Palabras clave

desastre natural, expansión urbana, planificación urbana, vacíos urbanos, Blumenau

\section{0 planejamento urbano e desastres}

socioambientais: 0 mito da expansão urbana em Blumenau/SC

Resumo Este artigo aborda a relação entre desastres socioambientais e planejamento urbano sob a definição das estratégias de expansão urbana em Blumenau, na região norte da cidade. Coloca-se que a cidade se viu modificada a partir de dois processos: 1) os efeitos do planejamento urbano (derivado da ideia de uma cidade ideal); 2) os efeitos de desastres (gerados pela cidade real). Com base nesses dois processos, este artigo mostra que as estratégias do planejamento urbano e regional de Blumenau constituem marcadores sociais do efeito segregador dos desastres. Para desenvolver esse argumento, estrutura-se o texto em três seçôes principais: 1) A formação e o desenvolvimento urbano de Blumenau; 2) os desastres e o mito da expansáo urbana em direção à regiáo norte da cidade; e 3) a relaçáo entre desastres e limites do planejamento urbano.

Palavras-chave desastre natural, expansão urbana, planejamento urbano, vazios urbanos, Blumenau 


\section{Introduction}

The relationships between social-environmental disasters and urban dynamics are well known. On the one hand, most medium and large cities are placed in risk areas; on the other hand, it is in urban areas that the deaths and economic losses caused by disasters are concentrated (Sharifi 8 Yamagata, 2014; Nunes, 2015). In this way, the impacts of disasters can at the same time stimulate, delay or even prevent the implementation of population density policies and urban expansion. This process is related to both the types of disasters and the density and intensity of urban activities. Considering that Urban Planning (UP) can reduce or intensify the impacts of social-environmental disasters, it allows for the understanding of the Urban Planning and the Disaster Risk Management (DRM) "as complementary and non-exclusive” (Costa \& Ferreira, 2011, p. 3).

The 21st century can be considered the first century of human history in which the urban population exceeds the rural population in numbers. Currently, half of the world's seven billion people live in urban areas, and it is estimated that by 2050 the world's population will be more than 9 billion (United Nations [UN], 2015, 2017). Along with the more densely populated cities, the relational vision between cities and the environment has been transformed. The idea of city, as an artificial system superimposed on a natural system, has been understood as a single larger system of natural and social interrelations. The growing friction between the environment and the city has generated several ideological lines aimed at the environmentalization of planning. In this sense, the relationship between Urban Planning and the environment allows us to identify the types of planning that treat or intensify the occurrence and impact of disasters (Siebert, 2014).

The understanding that disasters are processes of social construction (Narváez, Lavell \& Ortega, 2009) allows us to highlight the sudden and expressive lack of balance between natural and social systems. More precisely, the understanding that disasters are not a problem of nature (Hewitt, 1983; Nunes, 2015) indicates the relevance of UP in mediating the interactions between the environment and the lack of organization and structuring of cities. Thus, it is possible to link disasters to the environmental approach of urban planning. According to Novak (2006), the urban problems associated with the environmental approach of UP "stem from the realistic view that both the ideal city and its quest through urban planning are myths" generated by the mismatch between a supposed "rational planning" and a management "negotiated with interests that widely use co-optation, corruption, and lobbying as forms of pressure" (Novak, 2006, p. 143).

The effects of social and environmental disasters are not homogeneously distributed in space. According to the social and environmental characteristics in a region, disasters can cause a double segregation inside the cities. On the one hand, they characterize the urban space in "safe" and "unsafe" areas; on the other hand, they concentrate the protection resources in the most valued areas. The combined effect of these processes is the widening of social inequalities: more valued areas become safer, and less valued areas become 
unsafer. This process of segregation materializes the dynamics of valorization and devaluation of urban spaces. This is because the more the protection is concentrated, the more widespread destruction will be. Consequently, unsafer areas end up concentrating more population. This relationship between UP and social-environmental disasters can be evidenced when analyzing the urban development pattern of Blumenau since 1850.

The question is: Why, despite having more than 40 years of Urban Planning in Blumenau, via four Executive Plans, has the city failed to reverse the relationship between urban development and the intensification of disaster impacts? In order to answer this question, it is necessary to consider the Urban Planning of Blumenau (UPB) through a problem-solution relationship. More precisely: The way in which the problem of disasters is perceived conditions the action strategies that seek to mitigate the risk of disasters. The UPB was consolidated based on the dynamics of industrial development, which pushes productive activities to the outskirts. However, the process of productive restructuring initiated in the 1990's shifted the local economy to the services sector, which tended to value central areas. By disregarding this economic inversion, the UPB ends up inducing an inadequate solution that intensifies the impact of disasters: The escape to the Northern Region of the city.

In this context, it is argued that the urban space of Blumenau was modified from two processes: 1) The effects of urban planning (generating the idea of an ideal city) segregated the city into safe and unsafe regions, which resulted in the myth of escape to the Northern Region of Blumenau; 2) the effects of disasters (generating the real city) triggered a double process of concentration of resources in the consolidated and more valued areas, intensifying the verticalization processes in the floodplain area (medium and high income population) and the occupation processes of the hills and slopes (low-income population). From these two processes, the UP strategies in Blumenau constitute social markers of the segregating effect of disasters. To develop this argument this text is structured in three main sections: 1) The formation and development of Blumenau; 2) the myth of urban escape to the Northern Region; 3) the relation of disasters and the limits of Urban Planning.

The methodology used has the bibliographical and documentary research on the formation and development of Blumenau as a starting point, with which the processes of formation of the colony, and of the industrial and services city are evidenced (first section). In order to identify and analyze UPB strategies in the face of social and environmental disasters, the research develops an analysis of the five Executive Plans implemented in the city since $1977(1977,1986,1996,2006$, 2018), comprising the 40 years of UPB guided by Executive Plans in the city (second section). Finally, a spatial analysis is performed in a Geographic Information System (GIS) environment, relating the urban voids, the infrastructure supply and the population density (third section), which seeks to present a scenario of the urban occupation of Blumenau and to make clear that urban spaces have to develop optimally and safely in the face of disasters.

This scientific research paper has as its main basis the five master plans published in the city in the last 40 years and the demographic data produced by the Brazilian Institute of Geography and Statistics (IBGE). It also has historical data on urban occupation available in the references. With regard to the data on the occupation pattern of the city, the article counts on the data produced by the Municipality of Blumenau (PMB), on subjects such as verticalization, spreading, area susceptible to floods and mass movement, as well as the useful area available for occupation in the municipality. 


\section{Formation and urban development of Blumenau/SC}

Threats turn into disasters starting from the existence of human variables. In other words, the impact of the disaster on a given population is related to its vulnerability (Moura \& Silva, 2008; Bankoff, Frenks \& Hilhorst, 2013). In addition, this tendency is socially built and stems from various factors, such as the occupation of territory, the social-economical development of the occupied region, as well as decisions and actions at all levels of management. To understand the processes of vulnerability of a population it is necessary to know its history, as well as the physical and spatial aspects of the territory. Blumenau is located in a region of great geo-ecological fragility. The Brazilian municipality, with 309,000 inhabitants, is located in the Middle Itajaí Valley (State of Santa Catarina), more precisely in the Itajaí-Açu River basin. The territory has $519.8 \mathrm{~km}^{2}$ and borders with the municipalities of Jaraguá do Sul and Massaranduba (North), Guabiruba and Botuverá (South),
Luis Alves and Gaspar (East), and Timbó, Indaial and Pomerode (West).

The basin of the Itajaí River has its relief formed by narrow valleys and small flat strips along the watercourses. The topography has great geo-ecological complexity. This complexity makes the region susceptible to the dynamics of erosive processes by environmentally weakening the area. In November 2008, Blumenau was hit by a sequence of events whose severity and impact changed the conception of disasters known until then in the state of Santa Catarina. Disaster susceptibility, such as those occurred in Blumenau in 2008, and the risk of flooding is extremely high (Frank \& Sevegnani, 2009). The colonization of Blumenau began in September 1850, when a group of 17 European settlers arrived at the region. Led by the German Hermann Bruno Otto Blumenau, the immigrants settled at the point where navigation on the Itajaí-Açu River was possible, the only access to the region at the time (Blumenau [HOB], 1958; Porath, 2004).

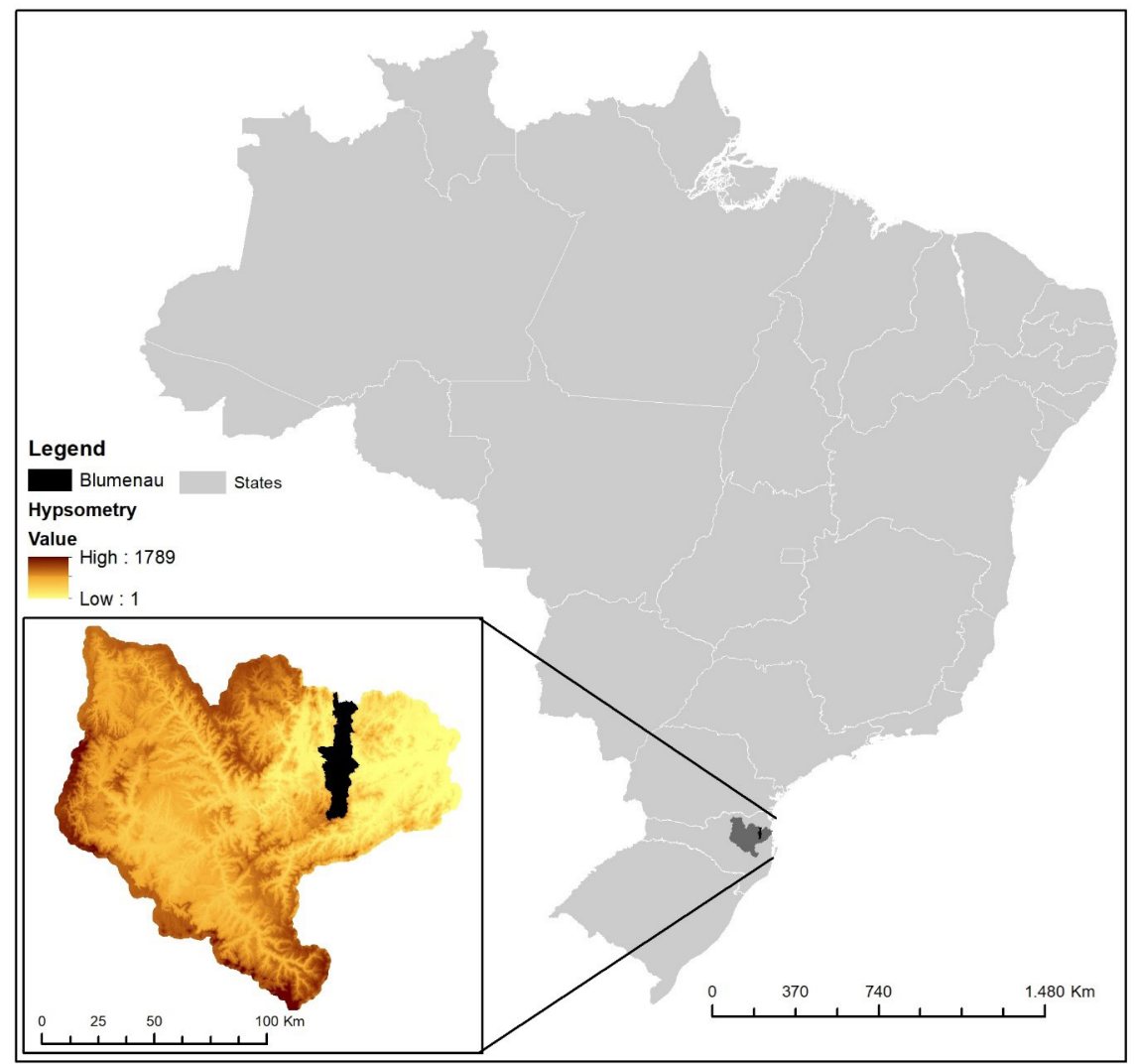

Figure 1. Itajaí Valley Basin, location of the city of Blumenau, State of Santa Catarina/BR 
The colonization model used was and is a determining factor for the urban development of Blumenau and other cities in the region, as well as for the agricultural practices of the colonizers.

The colonizers chose the floodplain area due to the settlement system used. This system settled population following the river's orientation. According to Siebert (2009), land plots were divided "into narrow, long slices, parallel to each other and perpendicular to the watercourses" (p. 42). The lots were 300 meters wide and 1,000 meters long. They usually started at the river's edge, then went up to the hills and slopes, and were linked together by trails. To make roads feasible, the settlers resorted to the cut of the slopes in those parts where the valleys narrowed and became steeper. It was this way, imprisoned between rivers and hills, that the trails were made and later became the road system of the cities in the region (Hering, 1987). According to Siebert (2009), "bottlenecks" have arisen, which still intensify the traffic jams and fall of barriers until today.

They chose this settlement system so that each family could receive a piece of land that had access to the water, because it was essential for planting and consumption. Thus, settlers were guaranteed land for planting, water for subsistence, and communication between all the lots of the colony through the trails and waterways of the river (Porath, 2004). This type of land distribution was very similar to the so-called Waldhufendorf (forest line) settlement model (Mamigonian, 1966; Siebert, 1996). This model, adopted for rural areas, was widely used in East Germany in the Middle Ages. For urban areas, there was another model. It joined the Waldbufendorf and was called Stadtplatz (place of the city) (Mamigonian, 1966; Porath, 2004). At the Stadplatz, the settlers lived in central areas near the waterways and were obliged to move to the land areas used for agriculture.
Later, another model of occupation emerged: the Strassendorf(Siebert, 1996), who accommodated settlers in their own lands. These three models of land demarcation determined the urban development of Blumenau and the agricultural practices of the settlers. Over time, and to support the trade of products from agriculture and services, small settlements were formed. These settlements were the beginning of new towns. The way the rural spaces were thought followed a pattern. This pattern was called Minimale Ackerbabrung and was characterized by the idea that a family needed a minimum amount of land. This amount was sufficient only for the development and conditioning of social-economical reproduction. This pattern motivated the commerce of land and attracted the colonizing companies. Thus, the smaller the land was, the more lots would be available for sale, and more immigrants would come to Blumenau.

During colonization, the clearing of forests was encouraged. The concern for the preservation of the native forest was non-existent. As mentioned above, the settlers tried to adapt the European farm practices to the region. On the one hand, these practices demanded intense soil revolving; on the other hand, they encouraged deforestation and burning. The immigrants even tried to adequate and adapt their practices to the region's environmental conditions, but this was not possible. The rugged topography and fragile soil of the Valley region, always subject to heavy rains, did not support the required movement. It was from this pattern of occupation of the geographic space, and from the way in which the colonizers used the available resources and realized the management of the ground, that arose the first records of emergencies in the state. That is, these occupation patterns triggered the processes of vulnerability of the population in Blumenau and the nearby region. 
In the 1960's, the municipality of Blumenau had about 50,000 inhabitants and some factories had more than 1,000 workers. In Brazil, the municipality was considered the 10th textile center. The industrialization of the city went through three different phases (Mamigonian, 1966): 1) The first phase occurred 30 years after the beginning of colonization and lasted until the advent of electricity and spinning factories; 2) the second phase occurred during World War I and was the period of the consolidation of industries, having as a characteristic the valorization and promotion of agricultural handcraft products, when new ventures arose and Blumenau attracted the attention of the region with its small textile, shoelaces, hats, bagpipes and furniture factories; 3) the third phase began in the 1930's and lasted until 1940. This last phase was affected by the industrial crisis of 1929. By that time, the municipality had its own bank and was already considered a regional metropolis.

With the advent of industrialization and the need to take advantage of hydraulic power in production, industries were built next to or near the waterways. This factor was decisive for the social production of emergencies in the city. As the factories were located on the outskirts and were distant from each other, small villages that stored the employees' residences arose around them. At that time, the municipality already possessed three forms of space occupation: 1) The peripheral rural zone that was located near the urban centers and was characterized by the agricultural production and the supply of the cities; 2) the suburban one, which was characterized by the colonist-worker who, in order to augment their income, cultivated the land between working days; and 3) the urban, which was structured in terms of commerce and services, because the largest industries, and their labor, were located in the periphery.
The production of the municipality was varied. The city produced everything from food products to crystals, bagpipes and dairy products. According to R. Lloyd, W. Feldwick, L. T. Delaney, and A. Wright (1913), Blumenau exported tobacco, sugar, wheat and dairy products to Hamburg and Bremen in Germany. However, industrialization occurred through the textile sector and this is how the city is known in Brazil to this day. The social-economical development of the city was accompanied by an increase in the population density and urbanization. The lands were depleted, the colonists were impoverished, and urbanization was intensified. In 1950, there was a reversal in demographic percentages between urban and rural areas. Until that decade, the majority of the population resided in rural areas. From that point on the majority of the population began to live in urban areas. Data from the Blumenau City Hall (BCH, 2010) and the Brazilian Institute of Geography and Statistics (IBGE, 2010) point to this phenomenon: The population in urban areas increased rapidly and the rural population reached very low levels, as shown in table 1 .

Table 1. Population of Blumenau through the decades

\begin{tabular}{|c|r|c|r|c|r|}
\hline YEAR & \multicolumn{1}{c}{ URBAN } & \multicolumn{1}{c}{ RURAL } & $\%$ & TOTAL \\
\hline 1950 & 24.443 & 50,8 & 23.665 & 49,2 & 48.108 \\
\hline 1960 & 47.740 & 71,5 & 19.038 & 28,5 & 66.778 \\
\hline 1970 & 86.519 & 86,3 & 13.756 & 13,7 & 100.275 \\
\hline 1980 & 146.001 & 92,8 & 11.257 & 7,2 & 157.258 \\
\hline 1991 & 186.190 & 87,9 & 25.645 & 12,1 & 211.835 \\
\hline 2000 & 241.943 & 92,4 & 12.011 & 7,6 & 261.808 \\
\hline 2010 & 294.773 & 95,3 & 14.238 & 4,7 & 309.011 \\
\hline Estimated population [2017] & & 348.513 \\
\hline
\end{tabular}

Source: own elaboration, with data from IBGE (2010)

In the 1950 's, the population of the municipality had reached 24,443 inhabitants in the urban area and 23,665 in the rural area, a still small difference, but that initiated the population inversion between the two areas. Comparing these data with the present time, Blumenau now presents 
a percentage of $95.39 \%$ of urban inhabitants and $4.61 \%$ of rural inhabitants. With the increase in population density in the urban area and the advent of the great floods came the verticalization of the constructions: Multi-storey buildings with their service and leisure areas on the ground floor due to flooding. With the high urban density, the city began growing in the outskirts, more precisely to areas of irregular occupation and risk. The verticalization, as an urban model, was thought for the middle class. According to Siebert, "for the low-income population, which cannot afford apartments, the option [...] was [to] climb the hills in a self-building system" (2009, p. 48).

For Siebert (2009) the social-economical exclusion had its consequences. It "generated, [...] a social-spatial exclusion, characterizing a socialenvironmental crisis" (Siebert, 2009, p. 48). According to the author, the occupation of irregular areas (landslide risk areas, precarious housing with fragile infrastructure) resulted in periodic disasters such as the one occurred in 2008. In that year, the disaster had two causes: 1) The natural one-irregular topography, fragile geology, and the intensity of rains occurring in the region; and 2) the human one-occupation of irregular areas, susceptible to landslides. The second reason stems from the fact that this type of occupation is cheaper in the real estate market and the policy of social housing in the municipality is ineffective. The formation and development of Blumenau in the face of disasters raises issues at the political level: what kind of answers has the State given throughout history? Moreover, what are the consequences of the State response model?

\section{Disasters and the myth of expansion to the Northern Region}

The formation of Blumenau indicates a controversial relationship between development and disasters. More precisely, the development that generates the conditions of vulnerability necessary for the occurrence and intensification of disasters is the same development that seeks to mitigate the impacts. In this sense, the debate on urban development and disasters in Blumenau has not sought to change the pattern of development, but rather to identify means to maintain this pattern and, at the same time, to mitigate the frequency and impact of disasters. At first, this posture stems from the physicalist paradigm (Gilbert, 1995), which includes disasters as external agents of development. In Blumenau, such an understanding is observed both in a regional scale with the construction of dams, and in a municipal scale with the construction of dikes. These are structural solutions that act only on the natural aspects of disasters in order to maintain land use and occupancy patterns.

With the intensification of impacts and the incorporation of the perspective that stated that disasters were products of development, the public power started, from the 1970's on, to control the expansion of the urban space of Blumenau. This new posture can be observed in the Directorial Plan (DP) of 1977 and becomes evident in the first revision of the DP (in 1989), when three macro zones are established for the city: 1) Southern Region: controlled density area due to its geomorphological characteristics; 2) Central Region: area of high density and consolidation; 3) Northern Region: area of urban expansion, less susceptible to flooding. This plan promotes the idea that the solution to minimize the occurrence and impact of disasters is to expand the city to the Northern Region as a strategy to escape disasters. While the growth is directed towards the North, and the urban density is controlled in the South (more vulnerable), the urban density in the Central Region is consolidated. This strategy remains in the Master Plans of 1996 and 2006. 
Since the 1977 DP, a set of urban norms has been developed aiming to shape the city according to the paradigm of escaping disasters; that is, expanding the city to the Northern Region. This paradigm was reinforced by the historical downpours of $1983 / 84$, which flooded more than $70 \%$ of the urbanized area (Siebert, 2009). With the expansion defined (figure 2), the 1989 Master Plan sought strategies to mitigate conflicts between urbanization processes and floods in the consolidated areas (mainly in the Central Region). Among the main strategies adopted are the prohibition of buildings and landfills in areas below the flood quota.$^{\circ} 10$ (BCH, 1989). Thus, one of the main guidelines of the 1989 DP was "to facilitate the coexistence with the periodic floods of the Itajaí-Açú river through the expansion of the city to flood-free regions; through the controlled verticalization of some already consolidated areas and through limitations to soil occupation in lower areas" (BCH, 1989, p. 02).

Thus, from the 1977 DP, one can perceive four main strategies of urban and regional planning in the face of disasters: 1) To direct the expansion of the city to the Northern Region (less susceptible to disasters); 2) to environmentally preserve the Southern Region (more susceptible to disasters);

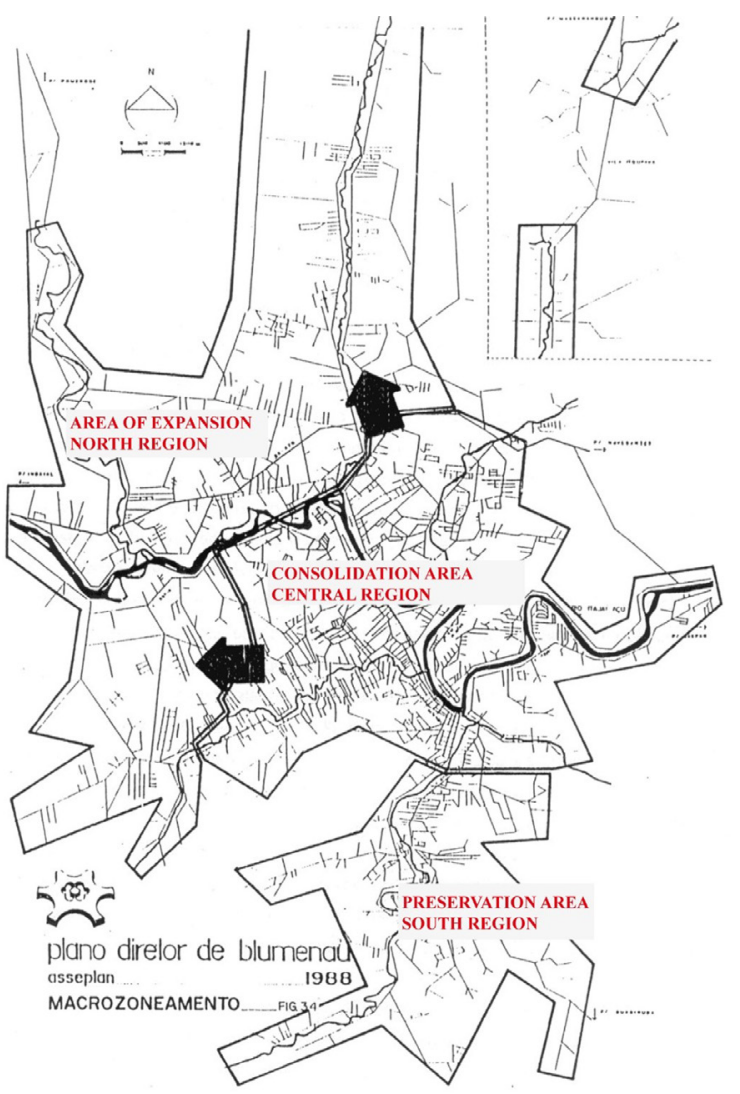

Figure 2. Macro-zoning of the 1989 Master Plan

Source: own elaboration from Blumenau City Hall (BCH, 1989)

3) to consolidate the Central Region (which has infrastructure, but is susceptible to floods); 4) to invest in structural solutions that aim to mitigate

\section{BLUMENAU URBANIZATION PROCESS}

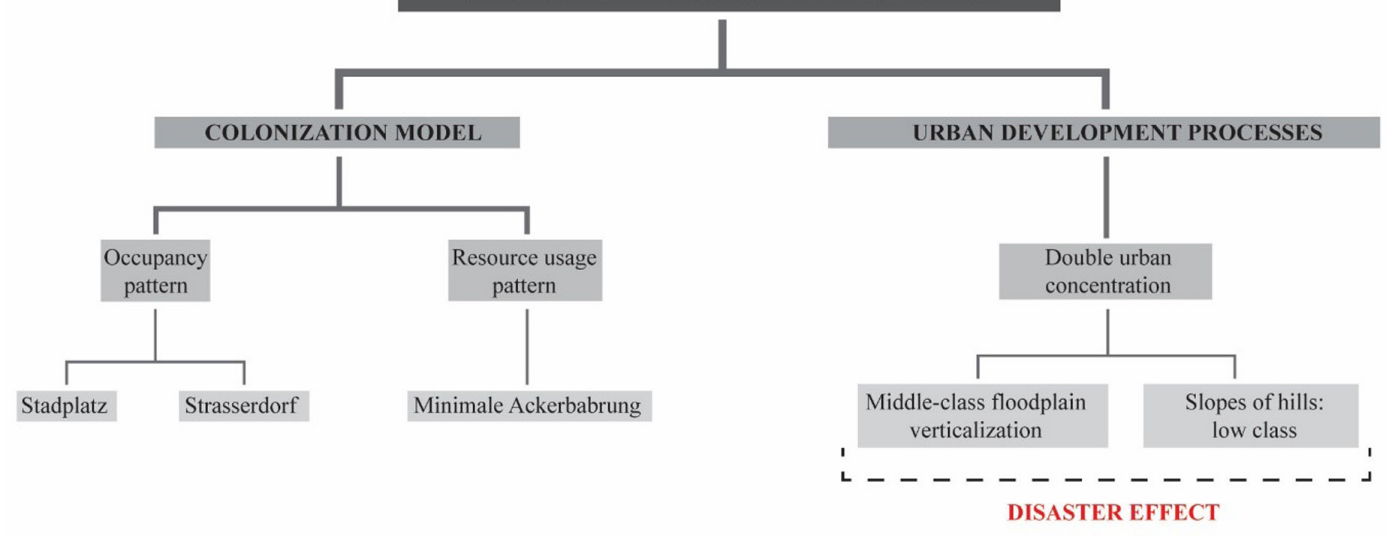

Figure 3. Blumenau urban development and the resulting models 
the impacts. However, according to Siebert, "the increasing complexity of urban planning legislation did not necessarily mean increasing state control over urban space" (2009, p. 49). While guidelines for expansion, environmental preservation, and consolidation have not been expressed territorially, the guidelines for investing in structural solutions to mitigate disaster risks were materialized in Blumenau and in the Region. It is possible to highlight the construction of dams in the cities of Taió and Ituporanga (Fraga, 2001).

As a result, disasters triggered a process of double urban concentration in the use and occupation of the soil in Blumenau from 1977 to 2018 (figure 3): 1) Model based on the verticalization of buildings by the middle/upper classes in flooded areas served by infrastructures, with multifamily designed buildings with garage and leisure area on the lower floors; 2) model based on the occupation of the nearby hills to the areas endowed with infrastructures by the population of low income, a model driven by self-construction and absence of social housing policies. On the one hand, the first model resulted in the increased density of areas susceptible to flooding (in quota 12), now inhabited by more than 30\% of the urban population. On the other hand, the second model resulted in landslides that occurred in November 2008, which changed the policy of disaster management in the city by incorporating the factors that involve mass movements (Siebert, 2009).

In addition to the disaster escape paradigm, another factor that guided the urban development guidelines was the belief in population estimates released by main institutions. The overpopulation paradigm was generated by the IBGE projections that indicated a population of 613,000 inhabitants in Blumenau in the year 2005 (Federation of Industries of the State of Santa Catarina [FIESC], 2006), which could demand the expansion of the urban perimeter to other regions of the city. However, with urban planning overshadowed by the escape paradigm, the support capacity of existing infrastructures, urban voids and the availability of flood-free areas for occupation in the different regions of the city were not thoroughly investigated. Due to the paradigms of escape and overpopulation, the expansion of the city was directed to the Northern Region, without the consolidated areas in the Central Region being investigated in order to identify the costs and the real need for urban expansion.

Almost 40 years after the first DP of Blumenau, the city has approximately 348,000 inhabitants (estimate of the IBGE for 2017), almost half of what was predicted for the year 2005. By relating the urban population density to the flood spot in quota 12, figure 5 makes evident the current population concentration in the Central Region of the city. More precisely, 32\% of the 309,011 inhabitants of Blumenau live in the census areas directly affected by floods in quota 12 (for population density calculations, the last IBGE census, published in 2010, was used). These data can confirm both the failure of the urban expansion guidelines that have acted on Blumenau for more than 40 years, as well as the materialization of the occupation model for the middle/upper classes, based on the verticalization and occupation of floodplain areas served by infrastructures and services. Thus, although the urban network indicates a spreading of the city (figure 4), neither the escape paradigm nor the overpopulation paradigm was expressed territorially. It should be noted that the discussion of urban sprawl is extensive in the literature (Harvey \& Clark, 1965; Squires, 2002), mainly by the critics of compact cities (Dieleman \& Wegener, 2004; Jenks \& Burgess, 2004). Therefore, thins concept is understood here as the expansion of the urban perimeter, accompanied by the pattern of occupation of low population density and little infrastructure. 


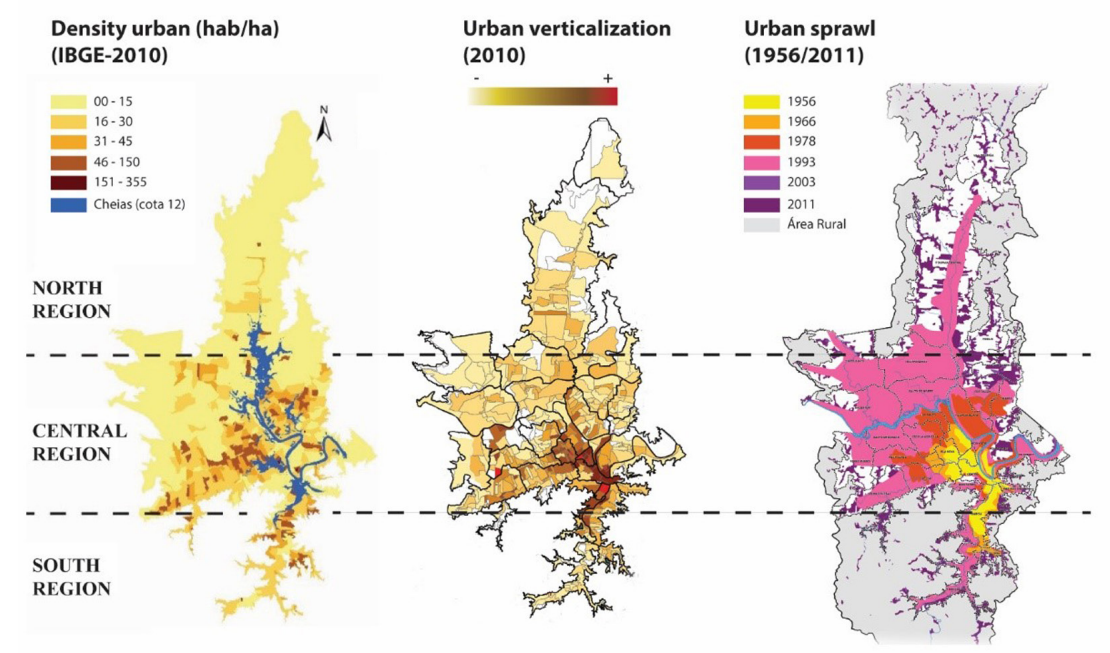

Figure 4. Urban area of Blumenau from three processes

Source: own elaboration, based on data from IBGE (2010) and BCH (2017)

Although urban sprawl did not take place, the planning and growth guidelines advocated for over 40 years (guided by the paradigms of escape and overpopulation) may have contributed to the intensification of two structural problems in the urban space of the city: 1) Urban mobility: instead of compacting the city and minimizing the need for displacement, the guidelines have caused a spreading effect, which encourages displacements of large routes in the Northern/Southern direction; 2) urban voids: there were no plans in the first four Master Plans which implemented an evaluation of the urban voids, and the real need to expand the city to the North. Both problems were potentialized by the deficiency in monitoring urban development in Blumenau. That is, there was no monitoring of land use and occupation capable of relating the population density to the capacity of support of infrastructures.

\section{Social-environmental disasters and the limits of urban planning}

In the period ranging from 1977 (first Master Plan) to 2018 (publication of the fifth Master Plan), the urban space in Blumenau was modified by two main processes: 1) The effects of urban planning (generated by the idealized city) segregated the city in "safe" and "unsafe" regions, which resulted in the "escape myth" to the Northern Region of Blumenau: the idea that the solution to the disasters would be to develop the city into a region free of disasters; 2) the effects of disasters (generated by the real city) triggered a double concentration in the consolidated and more valued areas, intensifying the verticalization in wetlands (the population of middle and high income) and the self-building in slope areas (by the low income population). From these two processes the strategies of the Urban Planning of Blumenau can constitute social markers of the segregating effect of disasters.

The fact that urban expansion to the North has not been implemented as planned may represent gains for the city in terms of infrastructure costs. This is because, although the planning directed the city towards the North, the urban infrastructure of Blumenau concentrated in the Central Region (figure 5). Thus if the desired expansion was effective, it would be necessary to meet new demands for infrastructure in the North, as well 


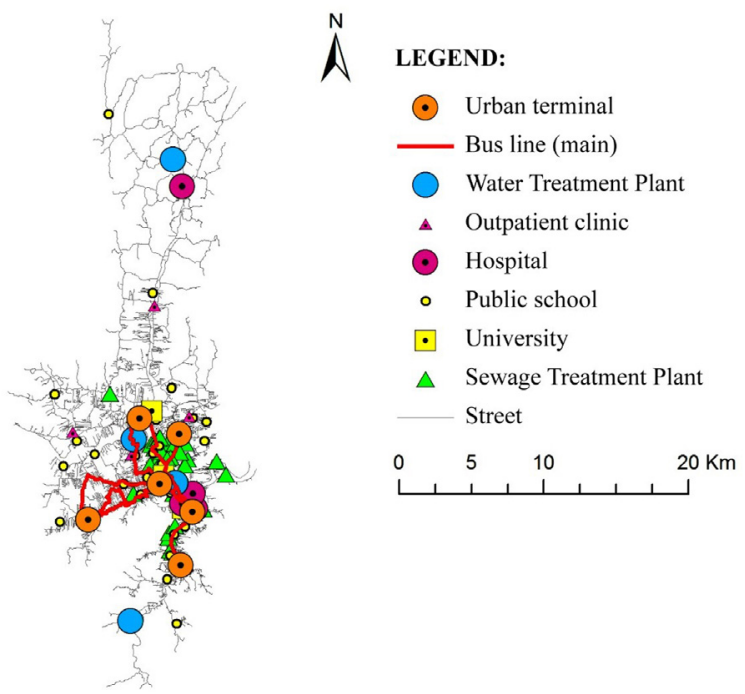

Figure 5. Concentration of the urban infrastructure in Blumenau in the Central Region

Source: own elaboration

as maintaining and optimizing existing infrastructure to supply the Central and Southern regions. This implies, for example, not only having to enlarge an already precarious sewage system with only 33\% coverage (Miglioli, Geremias, Dias, Bueno \& Greinert-Goulart, 2017), but also to expand infrastructures for mobility, water capture and treatment. In this sense, besides damaging the optimization of infrastructures in consolidated regions (Central Region), urban expansion would mean the need for investment in new infrastructures (Northern Region).

In order to examine the existing constraints in the urban area, the fifth Master Plan, which had its review started in 2015 and was published in 2018 , presented a precise analysis of the useful areas in the urban perimeter (empty and underutilized lots, with less than $5 \%$ of the utilization coefficient used) (BCH, 2017). In order to obtain the useful areas, the Board of Cartography, Multi-Purpose Register, and Information of the $\mathrm{BCH}$ considered all the existing restrictions in the municipality. Thus, the scenario of free suitable areas for occupation was obtained by subtracting the following information from the urban area: 1) Streets and widening of roads (official feedback); 2) Conservation Units; 3) Areas of Special Social Interest Zones (SSIZ); 4) Permanent Preservation Area (PPA) of hill tops and water courses (according to the Forestation Code); 5) slopes greater than 45\%; 6) Areas with Potential Risk (APR), these being the areas of Special Alert, Unincorporated Area of Medium and High Susceptibility (BCH, 2017).

In order to show the proportion of free suitable areas for occupation according to the different regions of Blumenau, the data obtained by the $\mathrm{BCH}$ (on the useful areas in Blumenau by neighborhood) were incorporated in this research and analyzed in a Geographic Information System (GIS). The analyses indicate that there are 26.16 $\mathrm{km}^{2}$ of empty or underutilized plots in the Central Region, equipped with infrastructure, and free of flood risks and mass movement (figure 6). While in the Northern Region the supply is significantly lower, with $12.24 \mathrm{~km}^{2}$ of useful floor area. This analysis makes it possible to confirm the historical limitations of the UPB in Blumenau, which for 40 years perceived the problem in a wrong way (lack of disaster-free space for occupation in the central part of the city) and, consequently, pointed out a wrong solution for urban development (expansion to the Northern Region, free of disasters). In this sense, it is possible to perceive limitations of Urban Planning in the face of the effects of social and environmental disasters, both in the capacity of planning to identify and monitor its own effects, and in the capacity to adjust as urban dynamics change.

On the one hand, the population and the main infrastructures are still concentrated in the Central Region; on the other hand, the Central Region of the city is still the region with the most useful area available for occupation, besides being the region with the greatest infrastructure (which may indicate that the city has not consistently occupied the available areas). In other words, 


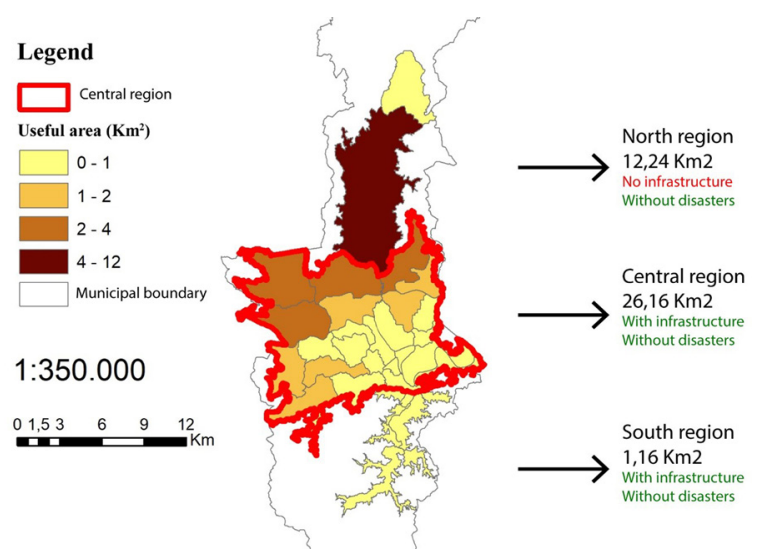

Figure 6. Urban useful area of Blumenau $\left(\mathrm{km}^{2}\right)$ free of mass movement and floods

Source: own elaboration, based on BCH data (2017)

both the urban expansion and the density and optimization of the infrastructure in the consolidated regions did not take place. This scenario indicates that the expansion strategies may have overshadowed planning in the search for sustainable urban development (in terms of a compact and efficient city), and in the search for effective solutions for the use and occupation of the soil in the face of the intensification of social and environmental disasters.

Urban Planning without due monitoring of its effects may constitute an obstacle both to risk mitigation and to sustainable urban development. This is because Urban Planning modifies and directs the development of urban space, which in turn concentrates the relations and dynamics of contemporary society, among them spatial patterns of vulnerability, such as land use and occupation. According to Pereira:

Social processes, such as urban planning and its products are generated from the form, structure and functions that the city previously presents. The city, its form and its dynamics are conditions for the spatial expression of relations in society. Urban planning is created, in this sense, from what already exists and already exerts influence. (2017, p. 242)
Thus, the urban space in Blumenau was modified, on the one hand, from the effects of urban planning that conceived an ideal city (due to the myth of escape to the Northern Region and the imaginary idea of a safe city); and, on the other hand, due to the effect of the disasters that generated the real city from a double concentration, with intensification of verticalization in the floodplain areas, and self-construction in slope areas (figure 7). This relationship between the real city and the idealized city is precisely observed by Pereira (2017), highlighting the role of the territory and the position of the urban planners in the elaboration of the Master Plans, which, instead of "understanding the city and then planning it, many imagined a future, from which they analyzed (judged) the present of the planned space (teleological vision): what was not according to the imagined future should be modified" (Pereira, 2017, p. 243).

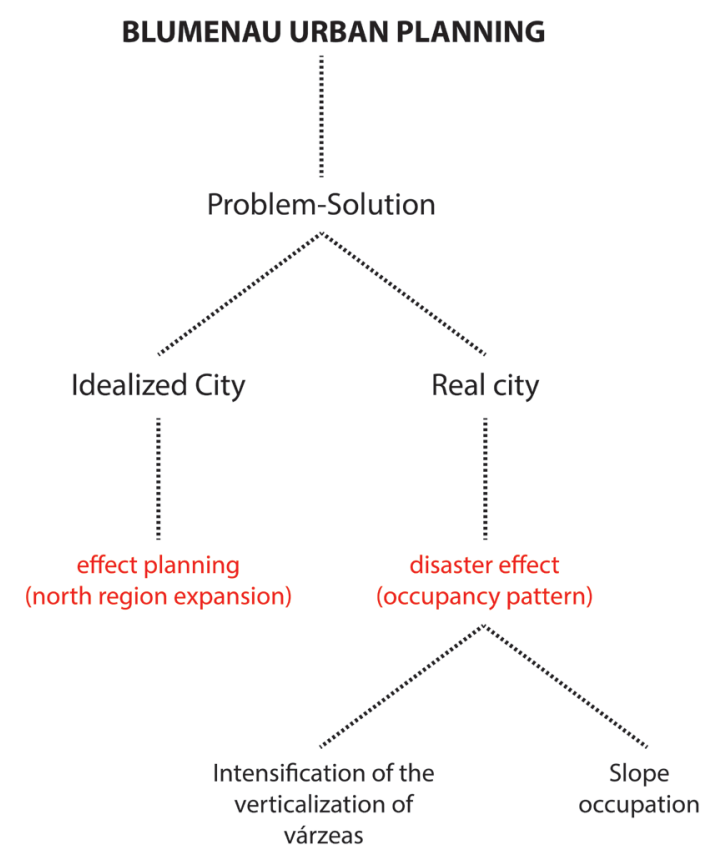

Figure 7. The effects of planning and disasters in the urban space of Blumenau

Source: own elaboration 


\section{Conclusion}

The historical relationship between the Urban Planning (UP) and the social and environmental disasters in Blumenau shows that disasters do not stem from problems caused solely by nature, but mainly from socially constructed processes such as land use and occupation. Through the analysis of the relationship between the UP and the social-environmental disasters, this text aimed to highlight the relevance of planning not only in the mitigation of disasters in the urban space, but also in the intensification and consolidation of socialenvironmental disasters as an urban problem. By identifying the problem of disasters in a wrong way in Blumenau (lack of useful areas in the central region of the city), the UP encouraged an also wrong solution (the expansion of the city to the North). However, due to the dynamics of disaster management, both the northern escape paradigm and the overpopulation paradigm have not been expressed territorially.

The dynamics of social and environmental disasters management promoted a double segregation in Blumenau. On the one hand, they characterized the urban space in "safe" and "insecure" areas; on the other hand, they concentrated the protection resources in the most valued areas and near the infrastructures of the city (floodplain areas of the Central Region). The effect of these processes was the expansion of social inequalities, that is, the most valued areas of floodplains became safer, and the less valued areas of slopes became unsafer. Consequently, unsafer areas of hillsides (with low market value) ended up concentrating more population. This dynamic resulted in an intense occupation of slopes and culminated in the historic tragedy that occurred in November 2008 in the region.

These two processes, which acted intensely in the city for more than 40 years, have consolidated complex social and cultural aspects. Although today the UP is clear about the useful areas of the municipality, the city crystallized its history and culture in floodplain and slope areas. In this sense, the questions that planning must answer in the coming years are also in the past (how to preserve the history and culture of the city, consolidated in risk areas, without encouraging the occupation model propagated in the last 40 years?), and in the future (how to encourage the occupation of the useful areas of the Central Region and, at the same time, discourage the population density in the North?). Answering these questions means redefining the development design built over the last 40 years. A first step in the search for a new approach was given when the UP identified the large supply of useful areas in the Central Region in the recent review of the 2018 Master Plan.

However, in order to redefine Blumenau's conception of urban development and to reverse its historical relationship with disaster intensification, it is essential to identify the real problem between Blumenau's Urban Planning and socialenvironmental disasters. If the problem is not natural, and if the problem is not the lack of useful area suitable for urban development, what is the problem, then? Being precise in identifying the problem means being precise in identifying the solution. The problem presented by the urban development of Blumenau after the induction of four Master Plans contributes to broadening the understanding of the relationships that can be established between Urban Planning and the social-environmental disasters. In other words, without adequate monitoring of its effects, the UP can both contribute to risk mitigation, and also be an obstacle.

In addition to redefining the design of urban development in Blumenau, the research indicates the need to rediscuss the urban perimeter of the municipality, discourage occupancy in 
risk areas (floodplains and slopes), and stimulate the occupation of available urban voids susceptible to occupation. The rediscussion about the urban perimeter of Blumenau undergoes paradigm shifts in the area of Urban Planning, since the city is located on lowland areas and has hills and slopes that have been occupied over time. Replanning the city, from a new conception of urban development, requires political will and recognition of the mistakes made in the past. Finally, it is necessary to reformulate the housing policy of the municipality since, in order to discourage the occupation of risk areas, the impoverished population of the city needs to have housing options in safer areas. These already exist, as this research demonstrated, and strategies are to be developed so that these housing options can be occupied.

\section{References}

Bankoff, G., Frerks, G., \& Hilhorst, D. (2013). Mapping Vulnerability: Disasters, Development \& People. London: Earthscan.

Blumenau City Hall (BCH). (1989). Law N. ${ }^{\circ}$ 3652/89 establishes a code of urban regulations and repealing the law N. ${ }^{\circ}$ 2235/77. Blumenau, Brazil.

Blumenau City Hall (BCH). (2010). Evolution of the population of Blumenau 1950-2010. Blumenau, Brazil. Retrieved from http://www. blumenau.sc.gov.br/downloads/seplan/relatorio_ BCH_censo_2010.pdf

Blumenau City Hall (BCH). (2017). Notebook 12, Diagnosis of Neighborhoods: Revision and updating of Complementary Law 615/2006-Master Plan of Blumenau. Blumenau, Brazil.

Blumenau (HOB). (1958). Fourth Report of the Colony Blumenau, Year 1853. Blumenau: Blumenau in Notebooks.
Brazilian Institute of Geography and Statistics (IBGE). (2010). Demographic Census of Brazil. Rio de Janeiro: IBGE.

Costa, E. B., \& Ferreira, T. A. (2011). Urban Planning and Risk Management: Life and Death in Brazilian Cities. Olam Science and Technology Magazine (UNESP), 10(2), 171-196.

Dieleman, F., \& Wegener, M. (2004). Compact City and Urban Sprawl. Built Environment, 30(4), 308-323. Retrieved from http:// www.spiekermann-wegener.com/pub/pdf/ Compact_city_BE.pdf

Federation of Industries of the State of Santa Catarina (FIESC). (2006). Santa Catarina in Data 2006. Florianópolis, Brazil.

Fraga, N. C. (2001). The floods in the Itajaí-Açú Valley: From the Containment Works to the Flood Industry-the Environmental Problem and the Man/Nature Relationship in the Search for Solutions. Raega-The Geographic Space in Analysis, 5(1), 125-149.

Frank, B., \& Sevegnani, L. (2009). 2008 Disasters in the Itajai Valley: Water, People and Politics. Blumenau: Water Agency of the Itajaí Valley.

Gilbert, C. (1995). Studying Disaster: A Review of the Main Conceptual Tools. International Journal of Mass Emergencies and Disasters, 13(3), 231-240. Retrieved from http://ijmed. org/articles/319/

Harvey, R. O., \& Clark, W. A. V. (1965). The Nature and Economics of Urban Sprawl. Land Economics, 41(1), 1-9. Retrieved from https:// www.jstor.org/stable/3144884?seq=1 
Hering, M. L. R. (1987). Colonization and Industry in the Itajai Valley: The Santa Catarina Model of Development. Blumenau: Edifurb.

Hewitt, K. (1983). The Idea of Calamity in a Technocratic Age. In K. Hewitt (Ed.), Interpretations of Calamity: from the Viewpoint of Human Ecology (pp. 3-32). London: Allen \& Unwin Inc.

Jenks, M., \& Burgess, R. (2004). Compact Cities: Sustainable Urban Forms for Developing Countries. London: Taylor \& Francis.

Lloyd, R., Feldwick, W., Delaney, L. T., \& Wright, A. (1913). Impressions of Brazil in the Twentieth Century: SEO, people, trade, institutes and resources. England: Loyd's Greater Britain Publishing Company.

Mamigonian, A. (1966). Geographical study of the industries of Blumenau. Rio de Janeiro: IBGE.

Miglioli, M. G., Geremias, J., Dias, J., Bueno, R. M., \& Greinert-Goulart, J. A. (2017). Removal of Cryptosporidium spp. oocysts and Giardia spp. cysts at a Waste Water Treatment Plant Garcia, in Blumenau, SC, Brazil. Revista Ambiente \& Água, 12(6), 1001-1016. Retrieved from http://www. scielo.br/scielo.php?script $=$ sci_abstract $\&$ pid $=S 1$ 980-993X2017000601001\&lng=en\&nrm=iso

Moura, R. De Andrade., \& Silva, L. (2008). Natural Disasters or Human Neglect? Revista Geografar, 3(1), 58-72.

Narváez, L., Lavell, A., \& Ortega, G. P. (2009). Disaster Risk Management: A Process-Based Approach. Lima: Secretaría General de la Comunidad Andina.

Novak, M. (2006). The Other Names of Urbanism: Urban Planning, Design and Design.
Cuadernos de Arquitectura y Urbanismo, 13(14), 127-146.

Nunes, L. H. (2015). Urbanization and Natural Disasters. São Paulo: Texts Workshop.

Pereira, E. M. (2017). How is participation? The Conditions for the Elaboration of Participative Director Plans. Brazilian Journal of Urban and Regional Studies, 19(2), 235-250.

Porath, S. L. (2004). The Landscape of Urban Rivers: The Presence of the River Itajai-Açu in the City of Blumenau (Doctoral dissertation). Federal University of Santa Catarina, Florianopolis.

Sharifi, A., \& Yamagata, Y. (2014). Resilient urban planning: Major principles and criteria. Energy Procedia, 61, 1491-1495. https://doi. org/10.1016/j.egypro.2014.12.154

Siebert, C. (1996). Structuring and Development of the Itajai Valley urban network. Blumenau: Edifurb.

Siebert, C. (2009). (Des)urban Control in the Itajaí Valley. In B, Frank \& L. Sevegnani (Eds.), 2008 Disaster in the Itajai Valley: Water, People and Politics (pp. 39-51). Blumenau: Edifurb.

Siebert, C. (2014). Urban Sustainability: Environmental Thinking and Cities. In S. I. M. Schult \& N. Bohn (Eds.), The Multiple Dimensions of Permanent Preservation Areas (pp. 41-65). Blumenau: Edifurb.

Squires, G. D. (2002). Urban Sprawl: Causes, Consequences, \& Policy Responses. Washington: The Urban Ed.

United Nations (UN). (2015). World Population Prospects: The 2015 Revision, Key Findings and Advance Tables. New York: United Nations. 
Retrieved from https://www.un.org/en/development/desa/publications/world-population-prospects-2015-revision.html
United Nations (UN). (2017). World Population Prospects: The 2017 Revision. New York: United Nations. Retrieved from https://population.un.org/wpp/Publications/Files/WPP2017_DataBooklet.pdf 